\title{
Phonon Sideband Analysis and Near-Infrared Emission in Heavy Metal Oxide Glasses
}

\author{
Joanna Pisarska $^{1, *}$, Wojciech A. Pisarski ${ }^{1}$, Radosław Lisiecki ${ }^{2}$ a and Witold Ryba-Romanowski ${ }^{2}$ \\ 1 Institute of Chemistry, University of Silesia, Szkolna 9 Street, 40-007 Katowice, Poland; \\ wojciech.pisarski@us.edu.pl \\ 2 Institute of Low Temperature and Structure Research, Polish Academy of Sciences, Okólna 2 Street, \\ 50-422 Wrocław, Poland; r.lisiecki@int.pan.wroc.pl (R.L.); w.ryba-romanowski@int.pan.wroc.pl (W.R.-R.) \\ * Correspondence: joanna.pisarska@us.edu.pl
}

Citation: Pisarska, J.; Pisarski, W.A.; Lisiecki, R.; Ryba-Romanowski, W. Phonon Sideband Analysis and Near-Infrared Emission in Heavy Metal Oxide Glasses. Materials 2021 14, 121. https://doi.org/10.3390/ ma14010121

Received: 15 November 2020 Accepted: 25 December 2020 Published: 30 December 2020

Publisher's Note: MDPI stays neutral with regard to jurisdictional clai$\mathrm{ms}$ in published maps and institutional affiliations.

Copyright: (C) 2020 by the authors. Licensee MDPI, Basel, Switzerland. This article is an open access article distributed under the terms and conditions of the Creative Commons Attribution (CC BY) license (https:// creativecommons.org/licenses/by/ $4.0 /)$.

\begin{abstract}
In this work, spectroscopic properties of europium and erbium ions in heavy metal oxide glasses have been studied. The phonon energy of the glass host was determined based on $\mathrm{Eu}^{3+}$ excitation spectra measurements. Near-IR emission spectra at $1550 \mathrm{~nm}$ related to ${ }^{4} \mathrm{I}_{13 / 2} \rightarrow{ }^{4} \mathrm{I}_{15 / 2}$ transition of erbium in heavy metal glasses were examined with special regards to luminescence bandwidth and measured lifetime. In particular, correlation between phonon energy and the measured lifetime ${ }^{4} \mathrm{I}_{13 / 2}\left(\mathrm{Er}^{3+}\right)$ was proposed. The luminescence lifetime for the ${ }^{4} \mathrm{I}_{13 / 2}$ upper laser state of erbium decreases with increasing phonon energy in glass matrices. Completely different results were obtained glass samples with europium ions, where the ${ }^{5} \mathrm{D}_{0}$ lifetime increases with increasing phonon energy. Our investigations suggest that the values of measured ${ }^{5} \mathrm{D}_{0}$ lifetime equal to radiative lifetimes for all heavy metal oxide glasses.
\end{abstract}

Keywords: heavy metal glasses; phonon sideband; rare earth ions; luminescence

\section{Introduction}

Heavy Metal Oxide Glasses (HMOG) are classified as promising amorphous systems, for which chemical durability and thermal stability are high, light transmission is wide and refractive indices are quite large compared to similar glasses without $\mathrm{PbO}[1-8]$. Heavy metal glass systems can be also quite easy synthesized because glass-forming compositional range is relatively wide. Among $\mathrm{HMOG}$ systems, $\mathrm{PbO}-\mathrm{GeO}_{2}$ glasses are considered to be one of the most promising amorphous materials for numerous applications. Lead germanate glasses containing Ag nanoparticles are recommended in photonics and catalysis [9]. Low-loss lead germanate-based glasses are useful for mid-infrared fiber optics $[10,11]$. They are also interesting from the structural point of view. The presence of minima or maxima in physicochemical properties of germanate-based glasses under addition of various network-modifiers usually well correlate with the coordination change $\mathrm{GeO}_{4}$ tetrahedra $\leftrightarrow \mathrm{GeO}_{6}$ octahedra, the formation of Ge-O-Ge bridging bonds and/or the creation of nonbridging oxygen atoms NBO's [12,13]. The structural mechanism responsible for the germanate anomaly well-known in the literature was proposed for glasses based on $\mathrm{PbO}-\mathrm{GeO}_{2}[14,15]$. Similar to germanate glass systems, this anomalous composition dependence of physicochemical properties was also observed for borate-based glasses [16,17].

On the other hand, HMOG glasses are excellent matrices to accommodate rare earth ions. Very recently, emission properties of rare earth ions in glasses based on $\mathrm{PbO}-\mathrm{GeO}_{2}[18,19]$, $\mathrm{PbO}-\mathrm{SiO}_{2}[20], \mathrm{PbO}_{-} \mathrm{B}_{2} \mathrm{O}_{3}[21,22]$ and $\mathrm{PbO}-\mathrm{P}_{2} \mathrm{O}_{5}[23,24]$ were examined in detail and their results were published last year. The additional glass-former components such as $\mathrm{Bi}_{2} \mathrm{O}_{3}$ and $\mathrm{TeO}_{2}$ were also added in order to improve properties of heavy metal oxide glasses responsible for white light emission [25]. Special attention was devoted to rare earths in silicate glasses containing $\mathrm{PbO}$, which emit near-infrared laser emission at about $2 \mu \mathrm{m}$ [26-30]. 
In this work, we present spectroscopic properties of europium and erbium ions in heavy metal oxide glasses. Phonon sideband analysis based on the excitation spectra measurements of europium and near-infrared emission properties at $1550 \mathrm{~nm}$ corresponding to main ${ }^{4} \mathrm{I}_{13 / 2} \rightarrow{ }^{4} \mathrm{I}_{15 / 2}$ laser transition of erbium are reported. Emission spectra of rare earth ions in heavy metal oxide glasses have been also examined previously by us. In particular, spectroscopic properties of $\mathrm{Eu}^{3+}$ ions in lead borate glass [31], lead phosphate glass [32] and glasses based on $\mathrm{PbO}-\mathrm{Ga}_{2} \mathrm{O}_{3}-\mathrm{XO}_{2}$, where $\mathrm{X}=\mathrm{Te}, \mathrm{Ge}, \mathrm{Si}$ [33] have been systematically studied. Preliminary results for $\mathrm{Er}^{3+}$ ions in heavy metal oxide and oxyhalide glasses, including their near-infrared emission properties and up-conversion processes, have been presented in a conference paper [34]. Comparison of measured luminescence lifetimes ${ }^{4} \mathrm{I}_{13 / 2}\left(\mathrm{Er}^{3+}\right)$ and ${ }^{5} \mathrm{D}_{0}\left(\mathrm{Eu}^{3+}\right)$ gives rather unexpected results. While dependence of the ${ }^{4} \mathrm{I}_{13 / 2}$ lifetime of erbium ions is well correlated with the phonon energies of the studied HMOG glass systems, the experimental results for luminescence decays from the ${ }^{5} \mathrm{D}_{0}$ excited state of europium are completely different. These aspects have not been examined in detail before. They are discussed here.

\section{Materials and Methods}

HMOG glasses with general formula $\mathrm{PbO}-\mathrm{Ga}_{2} \mathrm{O}_{3}-\mathrm{Me}_{\mathrm{x}} \mathrm{O}_{\mathrm{y}}-\mathrm{Ln}_{2} \mathrm{O}_{3}$ (Me denotes $\mathrm{Ge}, \mathrm{Si}$, $\mathrm{P}$ or $\mathrm{B}$ ) were synthesized. In the studied glasses, rare earth oxides $\mathrm{Ln}_{2} \mathrm{O}_{3}$ were limited to $\mathrm{Eu}_{2} \mathrm{O}_{3}$ and $\mathrm{Er}_{2} \mathrm{O}_{3}$. The following samples: (a) $45 \mathrm{PbO}-9.5 \mathrm{Ga}_{2} \mathrm{O}_{3}-45 \mathrm{GeO}_{2}-0.5 \mathrm{Ln}_{2} \mathrm{O}_{3}$, (b) $45 \mathrm{PbO}-9.5 \mathrm{Ga}_{2} \mathrm{O}_{3}-45 \mathrm{SiO}_{2}-0.5 \mathrm{Ln}_{2} \mathrm{O}_{3}$, (c) $45 \mathrm{PbO}-9.5 \mathrm{Ga}_{2} \mathrm{O}_{3}-45 \mathrm{P}_{2} \mathrm{O}_{5}-0.5 \mathrm{Ln}_{2} \mathrm{O}_{3}$ as well as (d) $45 \mathrm{PbO}-9.5 \mathrm{Ga}_{2} \mathrm{O}_{3}-45 \mathrm{~B}_{2} \mathrm{O}_{3}-0.5 \mathrm{Ln}_{2} \mathrm{O}_{3}$ (in mol\%) were prepared. Metal oxides of high purity were mixed in an agate ball mill for $2 \mathrm{~h}$ and then melted $\left(1100{ }^{\circ} \mathrm{C} / 0.5 \mathrm{~h}\right)$.

Fully amorphous glass plates (dimension $=10 \times 10 \mathrm{~mm}$, thickness $=2 \mathrm{~mm}$ ) confirmed by $X$-ray diffraction measurements were obtained. Differential scanning calorimeter DSC measurements (heating rate of $10^{\circ} \mathrm{C} / \mathrm{min}$ ) were performed with SETARAM Labsys thermal analyzer (SETARAM Instrumentation, Caluire, France). Spectra measurements (excitation and emission) were carried out using a Continuum Model Surelite I optical parametric oscillator coupled with Nd:YAG laser (Continuum Surelite OPO and SLI-10 Nd:YAG laser, Santa Clara, CA, USA). Also, the laser system consists of 1-m double grating monochromator, photomultiplier, and Stanford SRS250 boxcar integrator. Resolution for spectra measurements was $\pm 0.2 \mathrm{~nm}$. Decay curves were measured using oscilloscope Tektronix TDS3052 (two channel color digital phosphor oscilloscope, $500 \mathrm{MHz}$, Tektronix Inc., Beaverton, OR, USA) with an accuracy of $\pm 2 \mu \mathrm{s}$.

\section{Results and Discussion}

HMOG glasses were prepared by traditional melt quenching technique. In all glass samples, the ratio of heavy metal oxide $\mathrm{PbO}$ to $\mathrm{Me}_{\mathrm{x}} \mathrm{O}_{\mathrm{y}}$ seems to be 1:1, whereas molar concentration of $\mathrm{Ga}_{2} \mathrm{O}_{3}$ and $\mathrm{Ln}_{2} \mathrm{O}_{3}$ is equal to $9.5 \%$ and $0.5 \%$, respectively. Previous studies for boro-bismuth [35] and tellurite [36] glasses demonstrate significant role of $\mathrm{Ga}_{2} \mathrm{O}_{3}$ as a glass modifier, when its concentration is relatively low (usually less than 10 molar \%). For the studied HMOG systems, the glass transition temperature $\mathrm{T}_{\mathrm{g}}$ was determined based on DSC measurements. The values of $\mathrm{T}_{\mathrm{g}}$ are changed in the following direction $\mathrm{PbO}$ -

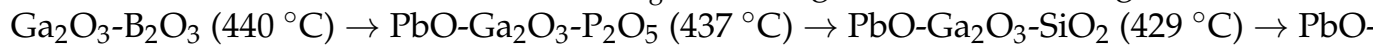
$\mathrm{Ga}_{2} \mathrm{O}_{3}-\mathrm{GeO}_{2}\left(384^{\circ} \mathrm{C}\right)$. Further investigations for lead borate glass [37] and lead phosphate glass [38] indicate that the glass transition temperatures are reduced with increasing $\mathrm{PbF}_{2}$ content. Ternary HMOG glasses based on $\mathrm{PbO}-\mathrm{Ga}_{2} \mathrm{O}_{3}-\mathrm{Me}_{\mathrm{x}} \mathrm{O}_{\mathrm{y}}(\mathrm{Me}=\mathrm{Ge}, \mathrm{Si}, \mathrm{P}, \mathrm{B})$ were singly doped with $\mathrm{Ln}^{3+}(\mathrm{Ln}=\mathrm{Eu}, \mathrm{Er})$ in order to study their spectroscopic and emission properties. Figure 1 shows the energy level diagrams for rare earth $\left(\mathrm{Eu}^{3+}\right.$ and $\left.\mathrm{Er}^{3+}\right)$ ions. All main emission lines corresponding to the ${ }^{5} \mathrm{D}_{0} \rightarrow{ }^{7} \mathrm{~F}_{1}$ (orange line) and ${ }^{5} \mathrm{D}_{0} \rightarrow{ }^{7} \mathrm{~F}_{2}$ (red line) transitions of europium ions and the ${ }^{4} \mathrm{I}_{13 / 2} \rightarrow{ }^{4} \mathrm{I}_{15 / 2}$ (near-IR line) transition of erbium ions are also indicated. It is worth noticing that the separation between the excited state ${ }^{5} \mathrm{D}_{0}$ and the next lower-lying state ${ }^{7} \mathrm{~F}_{6}$ of europium ions $\left(\Delta \mathrm{E}=12,500 \mathrm{~cm}^{-1}\right)$ is significantly larger than the ${ }^{4} \mathrm{I}_{13 / 2}{ }^{4} \mathrm{I}_{15 / 2}$ energy gap of erbium ions $\left(\Delta \mathrm{E}=6500 \mathrm{~cm}^{-1}\right)$. 


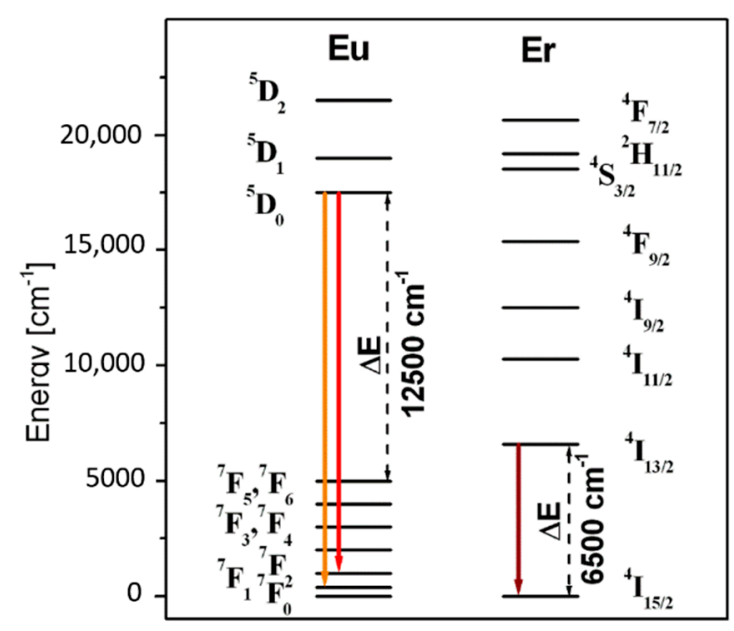

Figure 1. Energy level diagrams for trivalent europium and erbium ions.

\subsection{Phonon Sideband Analysis}

Figure 2 presents excitation and emission spectra of the studied HMOG systems containing europium ions. Insets show phonon sidebands PSB $\left(^{*}\right)$ and decays from the ${ }^{5} \mathrm{D}_{0}$ state of $\left.\mathrm{Eu}^{3+}{ }^{* *}\right)$. Luminescence spectra of glass samples excited at $464 \mathrm{~nm}\left({ }^{5} \mathrm{D}_{2}\right.$ state $)$ consist of several narrowed bands characteristic for europium ions. Two main emission bands at about $590 \mathrm{~nm}$ and $615 \mathrm{~nm}$ correspond to ${ }^{5} \mathrm{D}_{0} \rightarrow{ }^{7} \mathrm{~F}_{1}$ (orange) and ${ }^{5} \mathrm{D}_{0} \rightarrow{ }^{7} \mathrm{~F}_{2}$ (red) electronic transitions [39-42]. The relative ratio of their integrated emission intensities known as $\mathrm{R} / \mathrm{O}$ factor is changed in direction $\mathrm{PbO}-\mathrm{Ga}_{2} \mathrm{O}_{3}-\mathrm{B}_{2} \mathrm{O}_{3}(2.32) \rightarrow \mathrm{PbO}-\mathrm{Ga}_{2} \mathrm{O}_{3}-\mathrm{P}_{2} \mathrm{O}_{5}$ $(2.41) \rightarrow \mathrm{PbO}-\mathrm{Ga}_{2} \mathrm{O}_{3}-\mathrm{SiO}_{2}(3.00) \rightarrow \mathrm{PbO}-\mathrm{Ga}_{2} \mathrm{O}_{3}-\mathrm{GeO}_{2}$ (3.06).

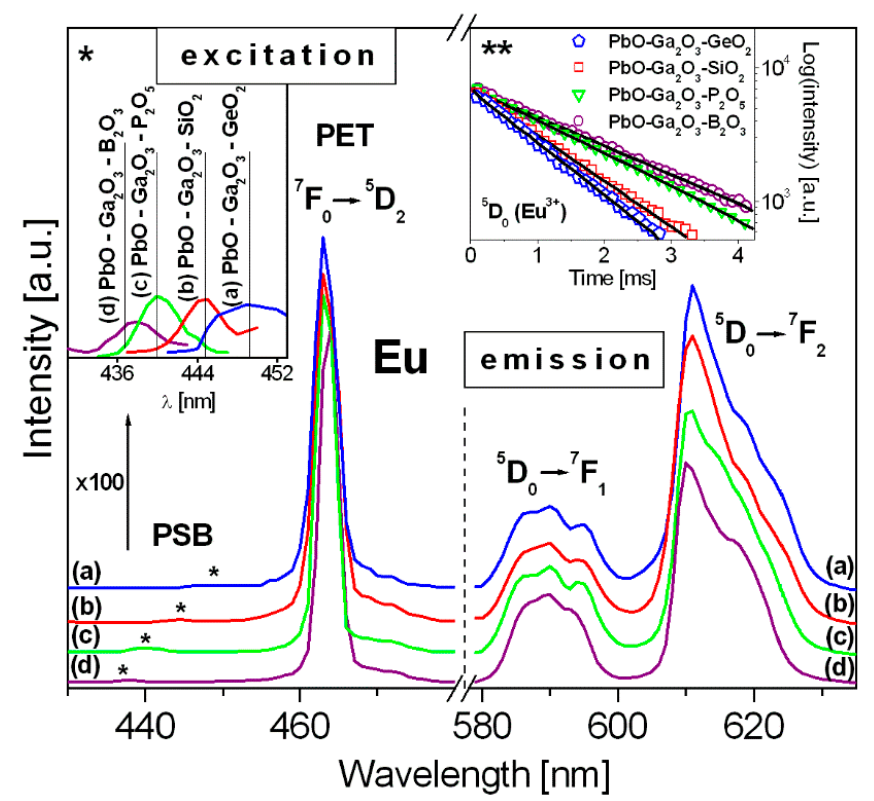

Figure 2. Excitation and luminescence spectra of HMOG glass systems containing europium ions. Phonon sidebands (PSB) and pure electronic transitions (PET) are shown. Insets present phonon sidebands $\left({ }^{*}\right)$ and decay curves for the ${ }^{5} \mathrm{D}_{0} \rightarrow{ }^{7} \mathrm{~F}_{2}$ transition of $\left.\mathrm{Eu}^{3+}{ }^{* *}\right)$.

Luminescence decays from the ${ }^{5} \mathrm{D}_{0}\left(\mathrm{Eu}^{3+}\right)$ state depend critically on the component $\mathrm{Me}_{\mathrm{x}} \mathrm{O}_{\mathrm{y}}$, i.e., $\mathrm{GeO}_{2}, \mathrm{SiO}_{2}, \mathrm{P}_{2} \mathrm{O}_{5}$ or $\mathrm{B}_{2} \mathrm{O}_{3}$, present in ternary HMOG glass. In fact, the ${ }^{5} \mathrm{D}_{0}$ $\left(\mathrm{Eu}^{3+}\right)$ measured lifetime diminishes in the following order: $\mathrm{PbO}-\mathrm{Ga}_{2} \mathrm{O}_{3}-\mathrm{B}_{2} \mathrm{O}_{3}(2.05 \mathrm{~ms}) \rightarrow$ $\mathrm{PbO}-\mathrm{Ga}_{2} \mathrm{O}_{3}-\mathrm{P}_{2} \mathrm{O}_{5}(1.85 \mathrm{~ms}) \rightarrow \mathrm{PbO}-\mathrm{Ga}_{2} \mathrm{O}_{3}-\mathrm{SiO}_{2}(1.27 \mathrm{~ms}) \rightarrow \mathrm{PbO}-\mathrm{Ga}_{2} \mathrm{O}_{3}-\mathrm{GeO}_{2}(1.11 \mathrm{~ms})$ To determine phonon energy of the host, the excitation spectra measurements of europium ions were successfully used. In 430-470 nm spectral range, two important bands of 
europium ions are located. They are assigned to pure electronic transition (PET) near $464 \mathrm{~nm}\left({ }^{7} \mathrm{~F}_{0} \rightarrow{ }^{5} \mathrm{D}_{2}\right.$ transition) and well-known in the literature transition dependent on the host (observed usually in the ranges $440-460 \mathrm{~nm}$ ), referred as phonon sideband PSB [43-45]. The phonon energy is difference between the positions of these bands (PSBPET). Their values for the studied HMOG glasses are given in Table 1. At this moment, it should be mentioned that the obtained results are also consistent with the experimental values from the Raman spectra measurements. The values obtained by two independent methods are nearly the same and difference does not exceed $\pm 3 \mathrm{~cm}^{-1}$. For example, the phonon energy for lead phosphate glass from Raman spectrum equal to $1120 \mathrm{~cm}^{-1}$ [46] is in a good agreement with the value obtained from the excitation spectrum measurement PSB-PET $=1117 \mathrm{~cm}^{-1}$ (Table 1). The same situation was observed for lead borate glass [31] and glasses based on $\mathrm{PbO}-\mathrm{Ga}_{2} \mathrm{O}_{3}-\mathrm{SiO}_{2}$ and $\mathrm{PbO}-\mathrm{Ga}_{2} \mathrm{O}_{3}-\mathrm{GeO}_{2}$ [33].

Table 1. Phonon energies (PSB-PET) determined from the excitation spectra measurements.

\begin{tabular}{cc}
\hline Heavy Metal Glass Host & PSB-PET $\left[\mathbf{c m}^{-1}\right]$ \\
\hline $\mathrm{PbO}-\mathrm{Ga}_{2} \mathrm{O}_{3}-\mathrm{GeO}_{2}$ & 775 \\
$\mathrm{PbO}-\mathrm{Ga}_{2} \mathrm{O}_{3}-\mathrm{SiO}_{2}$ & 950 \\
$\mathrm{PbO}-\mathrm{Ga}_{2} \mathrm{O}_{3}-\mathrm{P}_{2} \mathrm{O}_{5}$ & 1117 \\
$\mathrm{PbO}-\mathrm{Ga}_{2} \mathrm{O}_{3}-\mathrm{B}_{2} \mathrm{O}_{3}$ & 1320 \\
\hline
\end{tabular}

Like the ${ }^{5} \mathrm{D}_{0}$ luminescence lifetime, the phonon energy of the HMOG glass systems diminishes in the order $\mathrm{PbO}-\mathrm{Ga}_{2} \mathrm{O}_{3}-\mathrm{B}_{2} \mathrm{O}_{3}\left(1320 \mathrm{~cm}^{-1}\right) \rightarrow \mathrm{PbO}-\mathrm{Ga}_{2} \mathrm{O}_{3}-\mathrm{P}_{2} \mathrm{O}_{5}\left(1117 \mathrm{~cm}^{-1}\right) \rightarrow$ $\mathrm{PbO}-\mathrm{Ga}_{2} \mathrm{O}_{3}-\mathrm{SiO}_{2}\left(950 \mathrm{~cm}^{-1}\right) \rightarrow \mathrm{PbO}-\mathrm{Ga}_{2} \mathrm{O}_{3}-\mathrm{GeO}_{2}\left(775 \mathrm{~cm}^{-1}\right)$. The results are schematized in Figure 3.

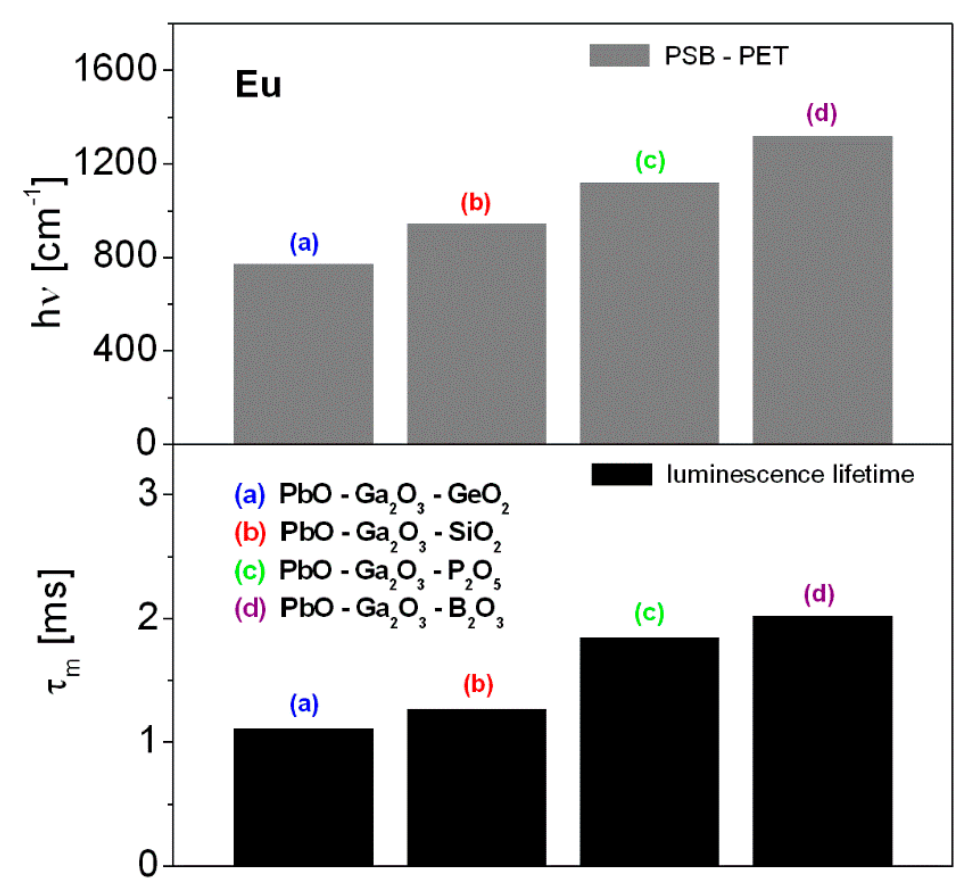

Figure 3. The influence of glass host composition on phonon energy and luminescence lifetime.

\subsection{Near-Infrared Emission}

Our previous investigations revealed that low-phonon heavy metal oxide and oxyhalide glass systems containing erbium are excellent amorphous hosts for near-IR radiation and up-conversion luminescence applications. In contrast to glasses based on $\mathrm{PbO}-\mathrm{Ga}_{2} \mathrm{O}_{3}-$ $\mathrm{GeO}_{2}$ and $\mathrm{PbO}-\mathrm{Ga}_{2} \mathrm{O}_{3}-\mathrm{SiO}_{2}$, the lack of up-conversion luminescence processes in PbO$\mathrm{Ga}_{2} \mathrm{O}_{3}-\mathrm{P}_{2} \mathrm{O}_{5}$ and $\mathrm{PbO}-\mathrm{Ga}_{2} \mathrm{O}_{3}-\mathrm{B}_{2} \mathrm{O}_{3}$ glass systems was confirmed, because $\mathrm{P}-\mathrm{O}$ and $\mathrm{B}-\mathrm{O}$ 
stretching vibrations are relatively large [34]. Further spectroscopic studies suggested that $\mathrm{PbO}-\mathrm{Ga}_{2} \mathrm{O}_{3}-\mathrm{GeO}_{2}$ and $\mathrm{PbO}-\mathrm{Ga}_{2} \mathrm{O}_{3}-\mathrm{SiO}_{2}$ glasses can be applied to up-conversion luminescence temperature sensors [47].

Figure 4 presents near-IR emission spectra measured for erbium ions in heavy metal oxide glass systems under excitation of ${ }^{4} \mathrm{~F}_{7 / 2}$ state by $488 \mathrm{~nm}$ laser line. Near-IR emission bands at about $1550 \mathrm{~nm}$ are assigned to main ${ }^{4} \mathrm{I}_{13 / 2} \rightarrow{ }^{4} \mathrm{I}_{15 / 2}$ transition of erbium. The inset shows emission decays from the ${ }^{4} \mathrm{I}_{13 / 2}$ state of trivalent erbium.

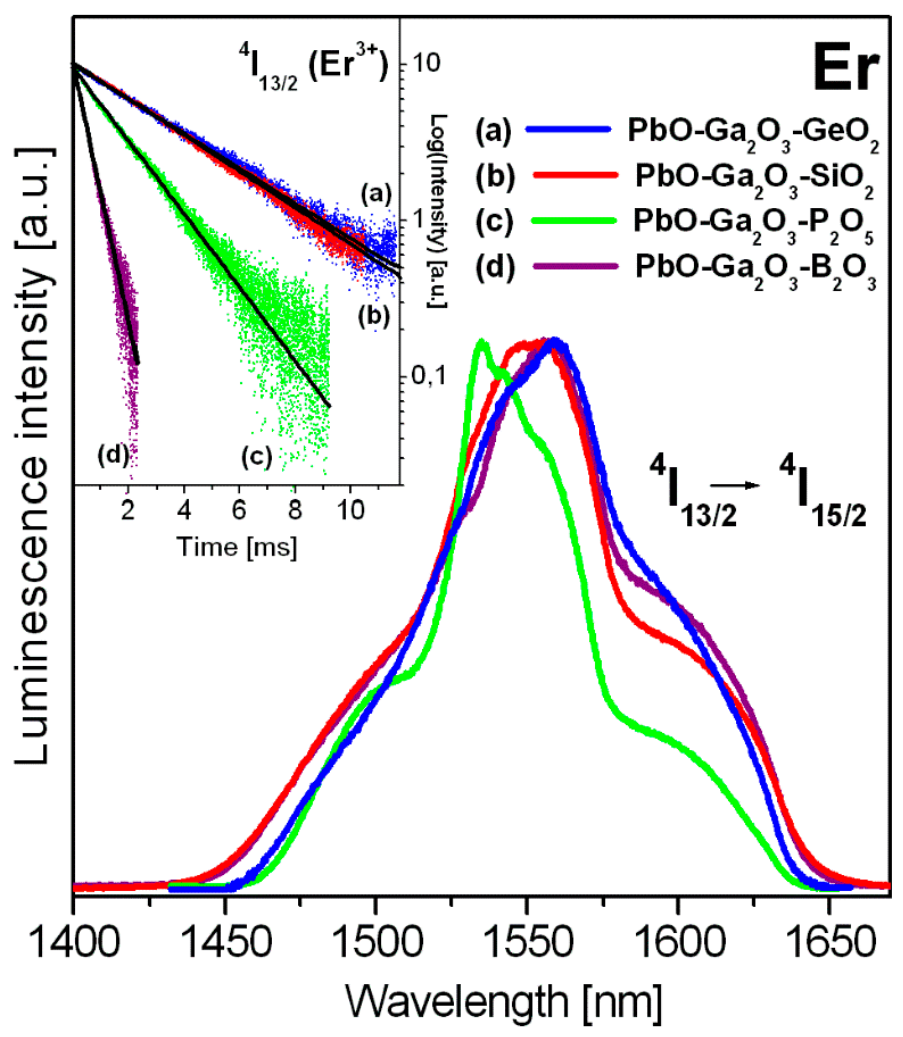

Figure 4. Normalized near-IR emission spectra for erbium ions in HMOG glass systems. Inset shows decays from the ${ }^{4} \mathrm{I}_{13 / 2}$ state of erbium.

Near-infrared emission spectra were normalized to compare the bandwidth for the ${ }^{4} \mathrm{I}_{13 / 2} \rightarrow{ }^{4} \mathrm{I}_{15 / 2}$ transition of erbium ions in HMOG glasses. The spectral bandwidth $\Delta \lambda$ given as full width in half maximum (FWHM) was determined. Furthermore, the luminescence lifetimes of ${ }^{4} \mathrm{I}_{13 / 2}$ state of erbium ions were calculated by fitting the luminescence decay curves. The bandwidth for the ${ }^{4} \mathrm{I}_{13 / 2} \rightarrow{ }^{4} \mathrm{I}_{15 / 2}$ transition of erbium ions is changed in the following direction $\mathrm{PbO}-\mathrm{Ga}_{2} \mathrm{O}_{3}-\mathrm{GeO}_{2} \rightarrow \mathrm{PbO}-\mathrm{Ga}_{2} \mathrm{O}_{3}-\mathrm{SiO}_{2} \rightarrow \mathrm{PbO}-\mathrm{Ga}_{2} \mathrm{O}_{3}-\mathrm{P}_{2} \mathrm{O}_{5}$, except for $\mathrm{PbO}-\mathrm{Ga}_{2} \mathrm{O}_{3}-\mathrm{B}_{2} \mathrm{O}_{3}$ glass system. The value of FWHM diminishes from lead germanate glass (nearly $88 \mathrm{~nm}$ ) to lead phosphate glass $(50 \mathrm{~nm})$. Quite large spectral bandwidth (above $90 \mathrm{~nm}$ ) for the ${ }^{4} \mathrm{I}_{13 / 2} \rightarrow{ }^{4} \mathrm{I}_{15 / 2}$ transition of erbium ions in $\mathrm{PbO}-\mathrm{Ga}_{2} \mathrm{O}_{3}-\mathrm{B}_{2} \mathrm{O}_{3}$ glass system was observed. The relatively large bandwidth is strongly required for near-IR laser systems as well as glass fiber amplifiers. It confirms our previous experimental results obtained for oxide and oxyhalide lead borate-based glass systems containing erbium ions [34,48]. However, near-IR emission of erbium ions comes from multiple peaks and the spectral profiles are not simple Gaussian in shape. For the studied HMOG systems, differences in spectral bandwidth are relatively small when full width at 10\% maximum (FW-10\% max) will be considered.

$\mathrm{Er}^{3+}$-doped heavy metal oxide glass containing $\mathrm{B}_{2} \mathrm{O}_{3}$ exhibits interesting properties (broadband emission), but the emission decay from the ${ }^{4} \mathrm{I}_{13 / 2}$ excited level of erbium is short when we compare to glass samples $\mathrm{PbO}-\mathrm{Ga}_{2} \mathrm{O}_{3}-\mathrm{Me}_{\mathrm{x}} \mathrm{O}_{\mathrm{y}}(\mathrm{Me}=\mathrm{Ge}, \mathrm{Si}$ or P). Both parameters, i.e., emission bandwidths and measured lifetimes are important spectroscopic 
factors and necessary to characterize glass materials with erbium for near-IR amplifiers [49]. The experimental results are schematized in Figure 5.

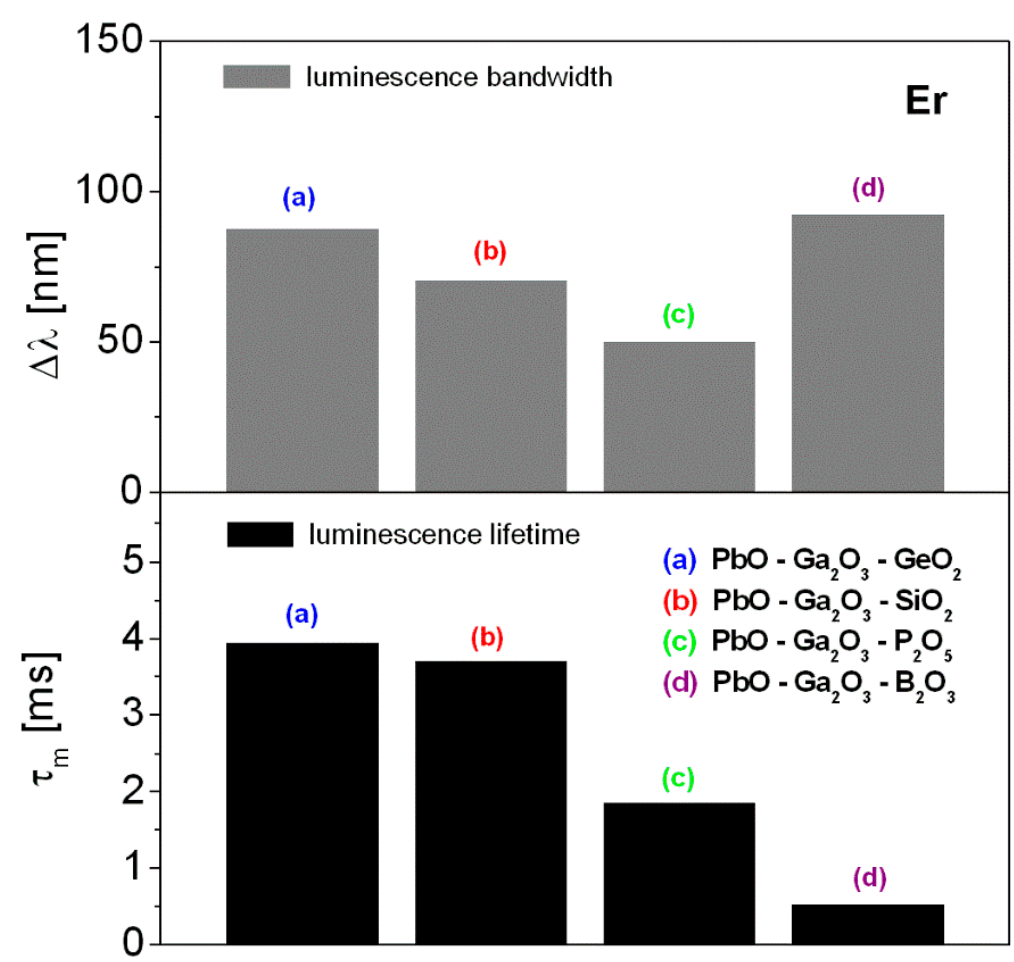

Figure 5. The influence of glass host composition on selected spectroscopic parameters $\left(\tau_{\mathrm{m}}, \Delta \lambda\right)$ determined for the ${ }^{4} \mathrm{I}_{13 / 2} \rightarrow{ }^{4} \mathrm{I}_{15 / 2}$ near-infrared laser transition of erbium.

It is experimental evidence that the multiphonon relaxation rates of rare earth ions increase with increasing phonon energy in the following direction $\mathrm{GeO}_{2} \rightarrow \mathrm{SiO}_{2} \rightarrow \mathrm{P}_{2} \mathrm{O}_{5}$ $\rightarrow \mathrm{B}_{2} \mathrm{O}_{3}[50,51]$. Borate-based glass systems have the highest phonon energy, whereas germanate amorphous materials have the smallest phonon energy among the studied HMOG glass systems. Thus, measured lifetimes of rare earths usually reduce because multiphonon relaxation rates are higher. Our experimental results confirm this hypothesis. The measured ${ }^{4} \mathrm{I}_{13 / 2}$ emission lifetimes of erbium ions are reduced from lead germanate glass $(3.9 \mathrm{~ms})$ to lead borate glass $(0.5 \mathrm{~ms})$ when phonon energy of the host increases.

Correlation between chemical composition, glass structure and properties was shown by various experimental techniques [52-54]. In particular, structure-property correlations in heavy metal oxyfluoride glass systems have been explored in a series of lead fluorogermanate and lead fluoroborate glasses, where the increasing $\mathrm{PbF}_{2}$ content results in enhanced luminescence lifetimes of rare earths. These effects are much less apparent in lead fluoroborate than lead fluorogermanate glasses [55]. Interesting structure-property relationships are also observed for our HMOG glass samples. We can conclude from emission measurements that spectroscopic properties of trivalent rare earths are not only critically dependent on the glass host composition. The phonon sideband analysis demonstrates that phonon energy increases from $\mathrm{PbO}-\mathrm{Ga}_{2} \mathrm{O}_{3}-\mathrm{GeO}_{2}$ to $\mathrm{PbO}-\mathrm{Ga}_{2} \mathrm{O}_{3}-\mathrm{B}_{2} \mathrm{O}_{3}$ glass system (see Table 1). The activator concentration $\left(\mathrm{Eu}^{3+}\right.$ and $\left.\mathrm{Er}^{3+}\right)$ for all studied glass samples is close to $0.5 \mathrm{~mol} \%$. The same experimental conditions were used for glass preparation, so the spectroscopic changes for rare earths (europium and erbium) are attributed to the change of the component $\mathrm{Me}_{\mathrm{x}} \mathrm{O}_{\mathrm{y}}$ (where $\mathrm{Me}=\mathrm{Ge}, \mathrm{Si}, \mathrm{P}, \mathrm{B}$ ) in HMOG glasses. Here, our investigations were limited to glass samples, where the molar ratio of the main oxide components is the same, i.e., $\mathrm{PbO}: \mathrm{GeO}_{2}=\mathrm{PbO}: \mathrm{SiO}_{2}=\mathrm{PbO}: \mathrm{P}_{2} \mathrm{O}_{5}=\mathrm{PbO}: \mathrm{B}_{2} \mathrm{O}_{3}=1: 1$. In fact, the ratios of structural units (the same concentrations of $\mathrm{Ge}, \mathrm{Si}, \mathrm{P}$ and $\mathrm{B}$ atoms) are also important and cannot be ignored. Thus, nature of glasses with the same fractions of Me network-former 
units should be analyzed in the future. However, the main comparison is made between $\mathrm{Eu}^{3+}$ and $\mathrm{Er}^{3+}$ doped samples. Our spectroscopic analysis based on decay curves clearly indicates that the dependence of measured lifetimes for the excited states of rare earth ions on phonon energies of HMOG glass hosts is completely different for the ${ }^{4} \mathrm{I}_{13 / 2}\left(\mathrm{Er}^{3+}\right)$ than the ${ }^{5} \mathrm{D}_{0}\left(\mathrm{Eu}^{3+}\right)$. Figure 6 shows schematically measured emission lifetimes for the ${ }^{5} \mathrm{D}_{0}$ $\left(\mathrm{Eu}^{3+}\right)$ and ${ }^{4} \mathrm{I}_{13 / 2}\left(\mathrm{Er}^{3+}\right)$ states as a function of the phonon energy of the HMOG system.

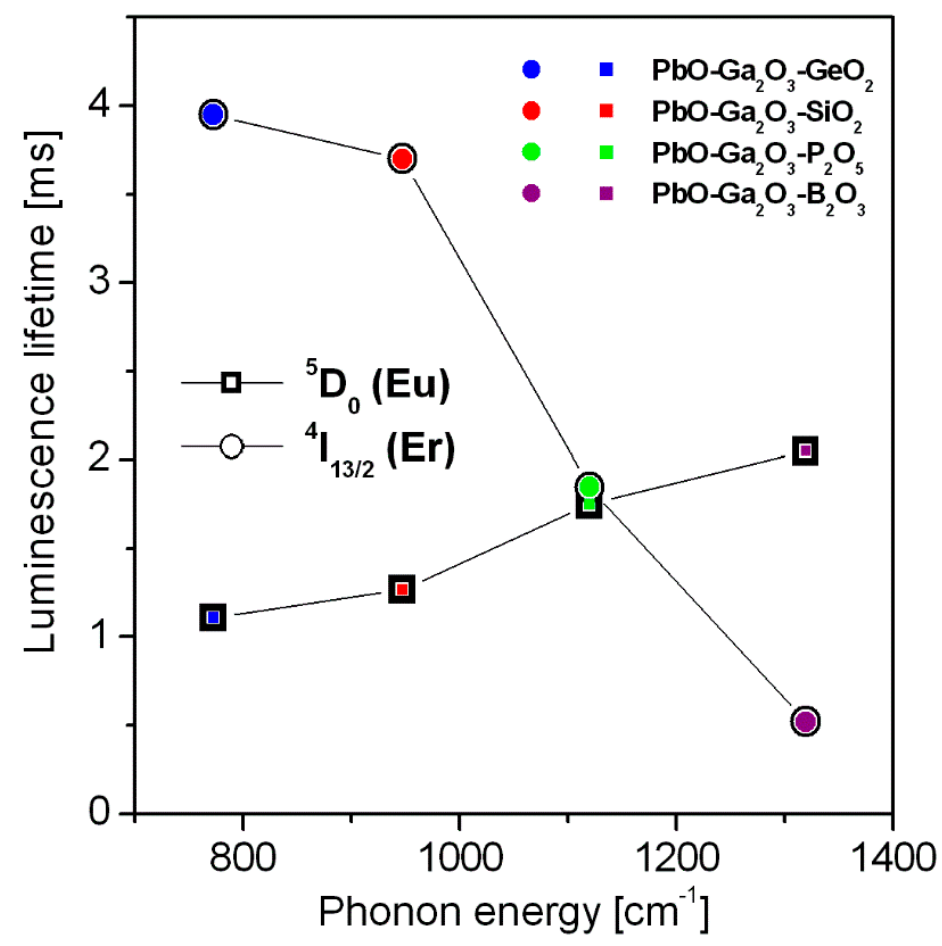

Figure 6. Lifetime for the ${ }^{5} \mathrm{D}_{0}\left(\mathrm{Eu}^{3+}\right)$ and ${ }^{4} \mathrm{I}_{13 / 2}\left(\mathrm{Er}^{3+}\right)$ excited states versus the phonon energy of the HMOG glass.

The measured lifetime for the ${ }^{4} \mathrm{I}_{13 / 2}$ upper laser state of erbium decreases, whereas lifetime for the ${ }^{5} \mathrm{D}_{0}$ state of europium increases with increasing phonon energy in glass matrices. Moreover, the change of the ${ }^{4} \mathrm{I}_{13 / 2}$ measured lifetime by a factor of 8 when the phonon energy changes from $775 \mathrm{~cm}^{-1}$ to $1320 \mathrm{~cm}^{-1}$ is very high as compared to about two-fold increase of the ${ }^{5} \mathrm{D}_{0}$ lifetime. This marked dissimilarity stems from the competition between radiative and multiphonon relaxation processes that remove the excitation of metastable levels of rare earth ions. The multiphonon relaxation consisting of simultaneous emission of the highest energy phonons in the lowest order process to cover the energy separation between a luminescent level and the next lower-lying energy level is consistent with the "energy gap law". Considering the ${ }^{4} \mathrm{I}_{13 / 2}$ metastable level located at about $6500 \mathrm{~cm}^{-1}$ above the next lower energy level ${ }^{4} \mathrm{I}_{15 / 2}$ and phonon energies gathered in Table 1 we obtain the lowest order values for multiphonon relaxation of $8,7,6$, and 5 for lead germanate, lead silicate, lead phosphate and lead borate glasses, respectively. We attribute observed dissimilarity of the ${ }^{4} \mathrm{I}_{13 / 2}$ lifetime values to the contribution of multiphonon relaxation rates, especially in lead borate and lead phosphate glasses where the orders of the process are relatively low. The results are completely different for the same glass host matrices containing europium ions, where the energy gap between excited level ${ }^{5} \mathrm{D}_{0}$ and the next lower level ${ }^{7} \mathrm{~F}_{6}$ is large $\left(\Delta \mathrm{E}=12500 \mathrm{~cm}^{-1}\right)$ in comparison to separation between ${ }^{4} \mathrm{I}_{13 / 2}$ and ${ }^{4} \mathrm{I}_{15 / 2}$ levels of erbium ions $\left(\Delta \mathrm{E}=6500 \mathrm{~cm}^{-1}\right)$ and non-radiative relaxation rates for rare earths are negligibly small. In fact, values of the order of multiphonon relaxation for the ${ }^{5} \mathrm{D}_{0}$ state of $\mathrm{Eu}^{3+}$ amount to $16,13,11$ and 10 for lead germanate, lead silicate, lead phosphate and lead borate glasses. Rates of multiphonon relaxation processes with orders of ten and higher are negligibly small. Therefore we can assume safely that measured 
luminescence lifetime values for europium-doped samples studied equal to radiative lifetimes of the ${ }^{5} \mathrm{D}_{0}$ state of $\mathrm{Eu}^{3+}$.

\section{Conclusions}

Near-IR emission spectra of $\mathrm{Er}^{3+}$ ions in four HMOG glass hosts based on PbO$\mathrm{Ga}_{2} \mathrm{O}_{3}-\mathrm{GeO}_{2}, \mathrm{PbO}-\mathrm{Ga}_{2} \mathrm{O}_{3}-\mathrm{SiO}_{2}, \mathrm{PbO}-\mathrm{Ga}_{2} \mathrm{O}_{3}-\mathrm{P}_{2} \mathrm{O}_{5}$ and $\mathrm{PbO}-\mathrm{Ga}_{2} \mathrm{O}_{3}-\mathrm{B}_{2} \mathrm{O}_{3}$ are presented and discussed. The near-IR emission bands correspond to the ${ }^{4} \mathrm{I}_{13 / 2} \rightarrow{ }^{4} \mathrm{I}_{15 / 2}$ transition of erbium. In particular, spectroscopic parameters for erbium ions such as emission bandwidth and lifetime were determined. Correlation between luminescence lifetimes for erbium ions and phonon energies of the HMOG systems has been proposed. The measured lifetime for the ${ }^{4} \mathrm{I}_{13 / 2}$ state of erbium ions decreases markedly with increasing phonon energy from $\mathrm{PbO}-\mathrm{Ga}_{2} \mathrm{O}_{3}-\mathrm{GeO}_{2}$ to $\mathrm{PbO}-\mathrm{Ga}_{2} \mathrm{O}_{3}-\mathrm{B}_{2} \mathrm{O}_{3}$ glass. Completely different results were obtained for the same glass host matrices containing europium ions, i.e., the measured lifetime for the ${ }^{5} \mathrm{D}_{0}$ state of $\mathrm{Eu}^{3+}$ increases with increasing phonon energy. Owing to large ${ }^{5} \mathrm{D}_{0}-{ }^{7} \mathrm{~F}_{6}$ energy gap, non-radiative multiphonon relaxation rates are negligibly small and experimental values of luminescence lifetimes are equal to radiative lifetimes for all HMOG glasses containing europium ions.

Author Contributions: Methodology, J.P., W.A.P., R.L., and W.R.-R.; formal analysis, W.A.P. and W.R.-R.; investigation, J.P., and R.L.; writing—original draft preparation, J.P. All authors have read and agreed to the published version of the manuscript.

Funding: This research received no external funding.

Data Availability Statement: The data presented in this study are available on request from the corresponding author.

Conflicts of Interest: The authors declare no conflict of interest.

\section{References}

1. Lezal, D.; Pedlikova, J.; Kostka, P.; Bludska, J.; Poulain, M.; Zavadil, J. Heavy metal oxide glasses: Preparation and physical properties. J. Non-Cryst. Solids 2001, 284, 288-295. [CrossRef]

2. Jayasankar, C.K.; Venkatramu, V.; Surendra Babu, S.; Babu, P. Luminescence properties of $\mathrm{Dy}^{3+}$ ions in a variety of borate and fluoroborate glasses containing lithium, zinc, and lead. J. Alloys Compd. 2004, 374, 22-26. [CrossRef]

3. Culea, E.; Pop, L.; Bosca, M. Structural and physical characteristics of $\mathrm{CeO}_{2}-\mathrm{GeO}_{2}-\mathrm{PbO}$ glasses and glass ceramics. J. Alloys Compd. 2010, 505, 754-757. [CrossRef]

4. Pisarska, J.; Zur, L.; Pisarski, W.A. Optical spectroscopy of $\mathrm{Dy}^{3+}$ ions in heavy metal lead-based glasses and glass-ceramics. J. Mol. Struct. 2011, 993, 160-166. [CrossRef]

5. Pisarski, W.A.; Grobelny, Ł.; Pisarska, J.; Lisiecki, R.; Ryba-Romanowski, W. Spectroscopic properties of $\mathrm{Yb}^{3+}$ and $\mathrm{Er}^{3+}$ ions in heavy metal glasses. J. Alloys Compd. 2011, 509, 8088-8092. [CrossRef]

6. Zur, L.; Sołtys, M.; Pisarska, J.; Pisarski, W.A. Absorption and luminescence properties of terbium ions in heavy metal glasses. J. Alloys Compd. 2013, 578, 512-516. [CrossRef]

7. Ersundu, A.E.; Çelikbilek, M.; Baazouzi, M.; Soltani, M.T.; Troles, J.; Aydin, S. Characterization of new $\mathrm{Sb}_{2} \mathrm{O}_{3}$-based multicomponent heavy metal oxide glasses. J. Alloys Compd. 2014, 615, 712-718. [CrossRef]

8. Kostka, P.; Ivanova, Z.G.; Nouadji, M.; Cernošková, E.; Zavadil, J. Er-doped antimonite $\mathrm{Sb}_{2} \mathrm{O}_{3}$-PbO-ZnO/ZnS glasses studied by low-temperature photoluminescence spectroscopy. J. Alloys Compd. 2019, 780, 866-872. [CrossRef]

9. Schneider, R.; Schneider, R.; de Campos, E.A.; Mendes, J.B.S.; Felix, J.F.; Santa-Cruz, P.A. Lead-germanate glasses: An easy growth process for silver nanoparticles and their promising applications in photonics and catalysis. RSC Adv. 2017, 7, 41479-41485. [CrossRef]

10. Wang, P.; Bei, J.; Ahmed, N.; Ng, A.K.L.; Ebendorff-Heidepriem, H. Development of low-loss lead-germanate glass for midinfrared fiber optics: I. glass preparation optimization. J. Amer. Ceram. Soc. 2021, 104, 860-876. [CrossRef]

11. Wang, P.; Ng, A.K.L.; Dowler, A.; Ebendorff-Heidepriem, H. Development of low-loss lead-germanate glass for mid-infrared fiber optics: II. preform extrusion and fiber fabrication. J. Amer. Ceram. Soc. 2021, 104, 833-850. [CrossRef]

12. Kamitsos, E.I.; Yiannopoulos, Y.D.; Karakassides, M.A.; Chryssikos, G.D.; Jain, H. Raman and infrared structural investigation of $x \mathrm{Rb}_{2} \mathrm{O}-(1-x) \mathrm{GeO}_{2}$ glasses. J. Phys. Chem. 1996, 100, 11755-11765. [CrossRef]

13. Barney, E.R.; Hannon, A.C.; Laorodphan, N.; Holland, D. Influence of Lone-Pair Cations on the Germanate Anomaly in Glass. J. Phys. Chem. C 2011, 115, 14997-15007. [CrossRef]

14. Rada, S.; Culea, E.; Rada, M. Towards understanding of the germanate anomaly in europium- lead-germanate glasses. J. Non-Cryst. Solids 2010, 356, 1277-1281. [CrossRef] 
15. Rada, M.; Aldea, N.; Wu, Z.H.; Jing, Z.; Rada, S.; Culea, E.; Macavei, S.; Balan, R.; Suciu, R.C.; Erhan, R.V.; et al. Evolution of the germanium-oxygen coordination number in lithium-lead-germanate glasses. J. Non-Cryst. Solids 2016, 437, 10-16. [CrossRef]

16. Kodama, M.; Kojima, S.; Feller, S.; Affatigato, M. Borate anomaly, anharmonicity and fragility in lithium borate glasses. Phys. Chem. Glasses 2005, 46, 190-193.

17. Sørensen, S.S.; Johra, H.; Mauro, J.C.; Bauchy, M.; Smedskjaer, M.M. Boron anomaly in the thermal conductivity of lithium borate glasses. Phys. Rev. Mater. 2019, 3, 075601.

18. Gunji, R.M.; Mattos, G.R.S.; Bordon, C.D.S.; Gomez-Malagon, L.A.; Kassab, L.R.P. Efficiency enhancement of silicon solar cells covered by $\mathrm{GeO}_{2}-\mathrm{PbO}$ glasses doped with $\mathrm{Eu}^{3+}$ and $\mathrm{TiO}_{2}$ nanoparticles. J. Lumin. 2020, 223, 117244. [CrossRef]

19. Khalid, M.; Lancaster, D.G.; Ebendorff-Heidepriem, H. Spectroscopic analysis and laser simulations of $\mathrm{Yb}^{3+} / \mathrm{Ho}^{3+} \mathrm{co}^{-\mathrm{dop}} \mathrm{ed}$ lead-germanate glass. Opt. Mater. Express 2020, 10, 2819-2833. [CrossRef]

20. Sun, Y.; Xin, W.; Meisong, L.; Hu, L.; Guzik, M.; Boulon, G.; Xia, L.; Kuan, P.-W.; Weiqinge, G.; Wang, T. Compositional dependence of Stark splitting and spectroscopic properties in $\mathrm{Yb}^{3+}$-doped lead silicate glasses. J. Non-Cryst. Solids 2020, 532, 119890. [CrossRef]

21. Venkata Rao, K.; Babu, S.; Balanarayana, C.; Ratnakaram, Y.C. Comparative impact of $\mathrm{Nd}^{3+}$ ion doping concentration on near-infrared laser emission in lead borate glassy materials. Optik 2020, 202, 163562. [CrossRef]

22. Deopa, N.; Sahu, M.K.; Rani, P.R.; Punia, R.; Rao, A.S. Realization of warm white light and energy transfer studies of $\mathrm{Dy}^{3+} / \mathrm{Eu}^{3+}$ co-doped $\mathrm{Li}_{2} \mathrm{O}-\mathrm{PbO}-\mathrm{Al}_{2} \mathrm{O}_{3}-\mathrm{B}_{2} \mathrm{O}_{3}$ glasses for lighting applications. J. Lumin. 2020, 222, 117166. [CrossRef]

23. Maity, A.; Jana, S.; Ghosh, S.; Sharma, S. Spectroscopic investigation on europium $\left(\mathrm{Eu}^{3+}\right)$ doped strontium zinc lead phosphate glasses with varied $\mathrm{ZnO}$ and $\mathrm{PbO}$ compositions. J. Non-Cryst. Solids 2020, 550, 120322. [CrossRef]

24. Basavapoornima, C.; Kesavulu, C.R.; Maheswari, T.; Pecharapa, W.; Depuru, S.R.; Jayasankar, C.K. Spectral characteristics of $\mathrm{Pr}^{3+}$-doped lead based phosphate glasses for optical display device applications. J. Lumin. 2020, 228, 117585. [CrossRef]

25. Marzouk, M.A.; Fayad, A.M. Heavy metal oxide glass responses for white light emission. J. Mater. Sci. Mater. Electron. 2020, 31, 14502-14511. [CrossRef]

26. Liu, X.; Huang, F.; Gao, S.; Wang, X.; Hu, L.; Chen, D. Compositional investigation of $\sim 2 \mu \mathrm{m}$ luminescence of Ho ${ }^{3+}$-doped lead silicate glass. Mater. Res. Bull. 2015, 71, 11-15. [CrossRef]

27. Liu, X.; Kuan, P.; Li, D.; Gao, S.; Wang, X.; Zhang, L.; Hu, L.; Chen, D. Heavily $\mathrm{Ho}^{3+}$-doped lead silicate glass fiber for $2 \mu \mathrm{m}$ fiber lasers. Opt. Mater. Express 2016, 6, 1093-1098. [CrossRef]

28. Tang, G.; Zhu, T.; Liu, W.; Lin, W.; Qiao, T.; Sun, M.; Chen, D.; Qian, Q.; Yang, Z. Tm ${ }^{3+}$ doped lead silicate glass single mode fibers for $2.0 \mu \mathrm{m}$ laser applications. Opt. Mater. Express 2016, 6, 2147-2157. [CrossRef]

29. Zhu, T.; Tang, G.; Chen, X.; Sun, M.; Qian, Q.; Chen, D.; Yang, Z. Two micrometer fluorescence emission and energy transfer in $\mathrm{Yb}^{3+} / \mathrm{Ho}^{3+}$ co-doped lead silicate glass. Int. J. Appl. Glass Sci. 2017, 8, 196-203. [CrossRef]

30. Wang, N.; Cao, R.; Cai, M.; Shen, L.; Tian, Y.; Huang, F.; Xu, S.; Zhang, J. Ho ${ }^{3+} / \mathrm{Tm}^{3+}$ codoped lead silicate glass for $2 \mu \mathrm{m}$ laser materials. Opt. Laser. Technol. 2017, 97, 364-369. [CrossRef]

31. Pisarska, J.; Pisarski, W.A. Lanthanide-Doped lead borate glasses for optical applications: A review. In Chapter 4 in Handbook on Borates: Chemistry, Production and Applications; Chung, M.P., Ed.; Nova Science Publishers, Inc.: New York, NY, USA, 2010; pp. 107-158.

32. Pisarski, W.A.; Żur, L.; Pisarska, J. Optical transitions of $\mathrm{Eu}^{3+}$ and $\mathrm{Dy}^{3+}$ ions in lead phosphate glasses. Opt. Lett. 2011, 36, 990-992. [CrossRef] [PubMed]

33. Pisarski, W.A.; Pisarska, J.; Zur, L.; Goryczka, T. Structural and optical aspects for $\mathrm{Eu}^{3+}$ and $\mathrm{Dy}^{3+}$ ions in heavy metal glasses based on $\mathrm{PbO}-\mathrm{Ga}_{2} \mathrm{O}_{3}-\mathrm{XO}_{2}(\mathrm{X}=\mathrm{Te}, \mathrm{Ge}, \mathrm{Si})$. Opt. Mater. 2013, 35, 1051-1056. [CrossRef]

34. Pisarski, W.A.; Pisarska, J.; Grobelny, Ł.; Lisiecki, R.; Ryba-Romanowski, W. Near-infrared luminescence and up-conversion processes of lanthanide ions in heavy metal glasses. Proc. SPIE 2011, 8001, 80012L.

35. Ling, Z.; Ya-Xun, Z.; Shi-Xun, D.; Tie-Feng, X.; Qiu-Hua, N.; Xiang, S. Effect of $\mathrm{Ga}_{2} \mathrm{O}_{3}$ on the spectroscopic properties of erbium-doped boro-bismuth glasses. Spectrochim. Acta A 2007, 68, 548-553. [CrossRef]

36. Mao, L.Y.; Liu, J.L.; Li, L.X.; Wang, W.C. $\mathrm{TeO}_{2}-\mathrm{Ga}_{2} \mathrm{O}_{3}-\mathrm{ZnO}$ ternary tellurite glass doped with $\mathrm{Tm}^{3+}$ and $\mathrm{Ho}^{3+}$ for $2 \mu \mathrm{m}$ fiber lasers. J. Non-Cryst. Solids 2020, 531, 119855. [CrossRef]

37. Zur, L.; Pisarska, J.; Pisarski, W.A. Influence of $\mathrm{PbF}_{2}$ concentration on spectroscopic properties of Eu $\mathrm{u}^{3+}$ and $\mathrm{Dy}^{3+}$ ions in lead borate glasses. J. Non-Cryst. Solids 2013, 377, 114-118. [CrossRef]

38. Pisarska, J.; Pisarski, W.A.; Goryczka, T.; Lisiecki, R.; Ryba-Romanowski, W. Thermal analysis and near-infrared luminescence of $\mathrm{Er}^{3+}$-doped lead phosphate glasses modified byPbF 2 . J. Lumin. 2015, 160, 57-63. [CrossRef]

39. Arunkumar, S.; Venkata Krishnaiah, K.; Marimuthu, K. Structural and luminescence behavior of lead fluoroborate glasses containing Eu ${ }^{3+}$ ions. Physica B 2013, 416, 88-100. [CrossRef]

40. Priyanka, R.; Arunkumar, S.; Basavapoornima, Ch.; Mathelane, R.M.; Marimuthu, K. Structural and spectroscopic investigations on $\mathrm{Eu}^{3+}$ ions doped boro-phosphate glasses for optical display applications. J. Lumin. 2020, 220, 116964. [CrossRef]

41. Roy, S.R.; Messaddeq, Y. Photoluminescence study of $\mathrm{Eu}^{3+}$ doped zinc-tungsten-antimonite glasses for red LED applications. J. Lumin. 2020, 228, 117608. [CrossRef]

42. Marcondes, L.M.; Santagneli, S.H.; Manzani, D.; Cassanjes, F.C.; Batista, G.; Mendoza, V.G.; da Cunha, C.R.; Poirier, G.Y.; Nalin, M. High tantalum oxide content in $\mathrm{Eu}^{3+}$-doped phosphate glass and glass-ceramics for photonic applications. J. Alloys Compd. 2020, 842, 155853. [CrossRef] 
43. Rajesh, M.; Reddy, G.R.; Sushma, N.J.; Devarajulu, G.; Deva Prasad Raju, B. Phonon sideband analysis, structural and spectroscopic properties of $\mathrm{Eu}^{3+}$ ions embedded $\mathrm{SiO}_{2}-\mathrm{B}_{2} \mathrm{O}_{3}-\mathrm{CaF}_{2}-\mathrm{NaF}-\mathrm{Na}_{2} \mathrm{O}$ glasses. Opt. Mater. 2020, 107, 110038. [CrossRef]

44. Manasa, P.; Jayasankar, C.K. Luminescence and phonon side band analysis of $\mathrm{Eu}^{3+}$-doped lead fluorosilicate glasses. Opt. Mater. 2016, 62, 139-145. [CrossRef]

45. Ramachari, D.; Rama Moorthy, L.; Jayasankar, C.K. Phonon sideband spectrum and vibrational analysis of Eu ${ }^{3+}$-doped niobium oxyfluorosilicate glass. J. Lumin. 2013, 143, 674-679. [CrossRef]

46. Pisarski, W.A.; Żur, L.; Goryczka, T.; Sołtys, M.; Pisarska, J. Structure and spectroscopy of rare earth-Doped lead phosphate glasses. J. Alloys Compd. 2014, 587, 90-98. [CrossRef]

47. Pisarski, W.A.; Pisarska, J.; Lisiecki, R.; Ryba-Romanowski, W. Sensitive optical temperature sensor based on up-conversion luminescence spectra of $\mathrm{Er}^{3+}$ ions in PbO-Ga $\mathrm{O}_{3}-\mathrm{XO}_{2}(\mathrm{X}=\mathrm{Ge}, \mathrm{Si})$ glasses. Opt. Mater. 2016, 59, 87-90. [CrossRef]

48. Pisarski, W.A.; Pisarska, J.; Lisiecki, R.; Grobelny, Ł.; Dominiak-Dzik, G.; Ryba-Romanowski, W. Erbium-doped oxide and oxyhalide lead borate glasses for near-infrared broadband optical amplifiers. Chem. Phys. Lett. 2009, 472, 217-219. [CrossRef]

49. Bradley, J.D.B.; Pollnau, M. Erbium-doped integrated waveguide amplifiers and lasers. Laser Photonics Rev. 2011, 5, 368-403. [CrossRef]

50. Layne, C.B.; Lowdermilk, W.H.; Weber, M.J. Multiphonon relaxation of rare-earth ions in oxide glasses. Phys. Rev. B 1977, 16, 10-20. [CrossRef]

51. Jackson, S.D.; Jain, R.K. Fiber-based sources of coherent MIR radiation: Key advances and future prospects. Opt. Express 2020, 28, 30964-31019. [CrossRef]

52. de Oliveira, M., Jr.; Gonçalves, T.S.; Ferrari, C.; Magon, C.J.; Pizani, P.S.; de Camargo, A.S.S.; Eckert, H. Structure-property relations in fluorophosphate glasses: An integrated spectroscopic strategy. J. Phys. Chem. C 2017, 121, 2968-2986. [CrossRef]

53. de Oliveira, M., Jr.; Uesbeck, T.; Gonçalves, T.S.; Magon, C.J.; Pizani, P.S.; de Camargo, A.S.S.; Eckert, H. Network structure and rare-earth ion local environments in fluoride phosphate photonic glasses studied by solid-state NMR and electron paramagnetic resonance spectroscopies. J. Phys. Chem. C 2015, 119, 24574-24587. [CrossRef]

54. Koudelka, L.; Kalenda, P.; Mošner, P.; Montagne, L.; Revel, B. Structure-property relationships in barium borophosphate glasses modified with niobium oxide. J. Non-Cryst. Solids 2016, 437, 64-71. [CrossRef]

55. Doerenkamp, C.; Carvajal, E.; Magon, C.J.; Faria, W.J.G.J.; Pedro Donoso, J.; Galvão Gobato, Y.; de Camargo, A.S.S.; Eckert, H. Composition-structure-property correlations in rare-earth-doped heavy metal oxyfluoride glasses. J. Phys. Chem. C 2019, 123, 22478-22490. [CrossRef] 